\title{
The Muscatine Button Workers' Strike of 1911-12
}

\section{An Iowa Community in Conflict}

\author{
Kate Rousmaniere
}

$\mathrm{T}_{\mathrm{H}}$

HE PASTORAL BACKDROP of an Iowa river town might not seem a likely setting for industrial strife. Labor uprisings at the turn of the century are more frequently envisioned in urban slums with overcrowded sweat shops and tenements jammed with immigrant workers. Muscatine, lowa was never so unfortunate. The small city on the bluffs of the Mississippi River was surrounded by the agrarian culture and economy of Iowa and Illinois. But lodged in this rural environment was a booming button industry that all but monopolized the city and the local labor force. The strike of the Muscatine button workers' union in 1911-12 is a significant example of the chaos inflicted on a rural community in the process of industrialization. The history of the strike includes the story of community dynamics as well as industrial conflict.

On February 25, 1911 a majority of the forty-three freshwater pearl button factories in Muscatine shut down production. The manufacturers claimed that the shutdown was due to overproduction. The 2,500 laid-off workers declared it was a threat against their newly organized union. The shutdown lasted one month, but the conflicts between the button workers' 
union and the manufacturers resulted in a fifteen-month boycott of the factories. ${ }^{1}$

This industrial strike was unusual in labor history in that it occurred in a small city in a state that led the nation in agricultural production. In such a setting, the progress and character of Iowa's industry and industrial laborers is very different from that of northeastern industrial states. Although Iowa was traditionally an agricultural state, at the turn of the century industry was growing rapidly. Urban-industrial centers grew in population between 1900 and 1910, drawing partly on rural migration to the cities. In 1910 Iowa's seventeen cities with populations of ten thousand or more inhabitants produced almost three-fourths of the state's total manufacturing value. In the five year period between 1904 and 1909, the total value of Iowa's industrial products had increased by 61 percent. This growth hardly placed Iowa at the top of industrial states. In 1909 less than 3 percent of the state's population were industrial wage earners and Iowa contributed less than 2 percent of all the nation's industries. While urban and industrial development was minimal in comparison to other states, this growth was substantial in relation to Iowa's smaller and more agrarian population. ${ }^{2}$

Agricultural supporters and popularized rural proponents reacted against urban industrialization in the Corn Belt. The dominant agrarian view of cities was as corrupt centers of immigrants, unions, and plutocrats, filled with diseases and indus-

1. The fifteen months that the Muscatine button workers' union was out of work have alternately been called a "lockout" and a "strike." The manufacturers called the factory closing a "shutdown" or "layoff." Four days after the incident the union declared it to be a "lockout," meaning the manufacturers had intentionally locked the workers out of the factories. As the situation developed in the following months, newspapers began to call the situation a "strike," meaning the union was intentionally boycotting the factories. The less incriminating terms "shutdown" and "boycott" are used here, except in circumstances where the manufacturers' locking out or the union's striking is the issue. The term "unionist" identifies only Muscatine button workers' union members.

2. U.S. Bureau of the Census, Thirteenth Census of the United States, 1910: Abstract of the Census with Supplement for Iowa (Washington, D.C., 1913), 683-684 (hereafter cited as Thirteenth Census). 
trial disasters. American agriculture was reaching its limit of expansion at the turn of the century and the migration to the cities caused serious concern to many Americans. "The men and women on the farm stand for what is fundamentally best and most needed in our American life," President Theodore Roosevelt told Congress in 1910, initiating the Country Life movement aimed at regenerating the rural areas of the nation. ${ }^{3}$

The comparatively smaller size of Iowa's industry and the distances between industrial centers contributed to the prevailing attitude that Iowa was only an agricultural state. Iowa differed from industrial states in that her industry was not concentrated in one central region. Six of the largest and most industrialized of the seventeen cities were on the eastern side of the state along the Mississippi River (Dubuque, Clinton, Davenport, Muscatine, Burlington, and Keokuk). All of these cities were in separate counties and none were closer than the twentyfive miles between Davenport and Muscatine. These distances served to lessen the overall impact of Iowa's industrial development, in contrast to the neighboring largely agrarian state of Illinois which had its industry concentrated in Chicago. The local and national lack of awareness of Iowa's industrial component resulted in the lack of concern and action for appropriate legislation within the state. ${ }^{4}$

Iowa's manufacturers were the first to complain that widespread agrarian attitudes were restricting urban-industrial interests in the state. They claimed that Iowa investors were more willing to lend to farms than to factories, that interest rates and average insurance rates were more than double those in some eastern states, and that the state's general assembly was suspicious and unsupportive of new industries. Iowa's industrial laborers were severely affected by the dominant rural attitudes. Iowa at the turn of the century was one of the few states in the nation with no laws or regulation protecting

3. William Bowers, "Farmers and Reformers in an Urban Age: The Country Life Movement and the 'Rural Problem,' 1900-1920" (M.A. thesis, University of Iowa, 1968), 172; "Report of the Country Life Commission," Document \#705, Congressional Documents, 60th Congress, 2nd Session.

4. Ruth A. Gallaher, Legal and Political Status of Women in Iowa (Iowa City: State Historical Society, 1918), 154. 


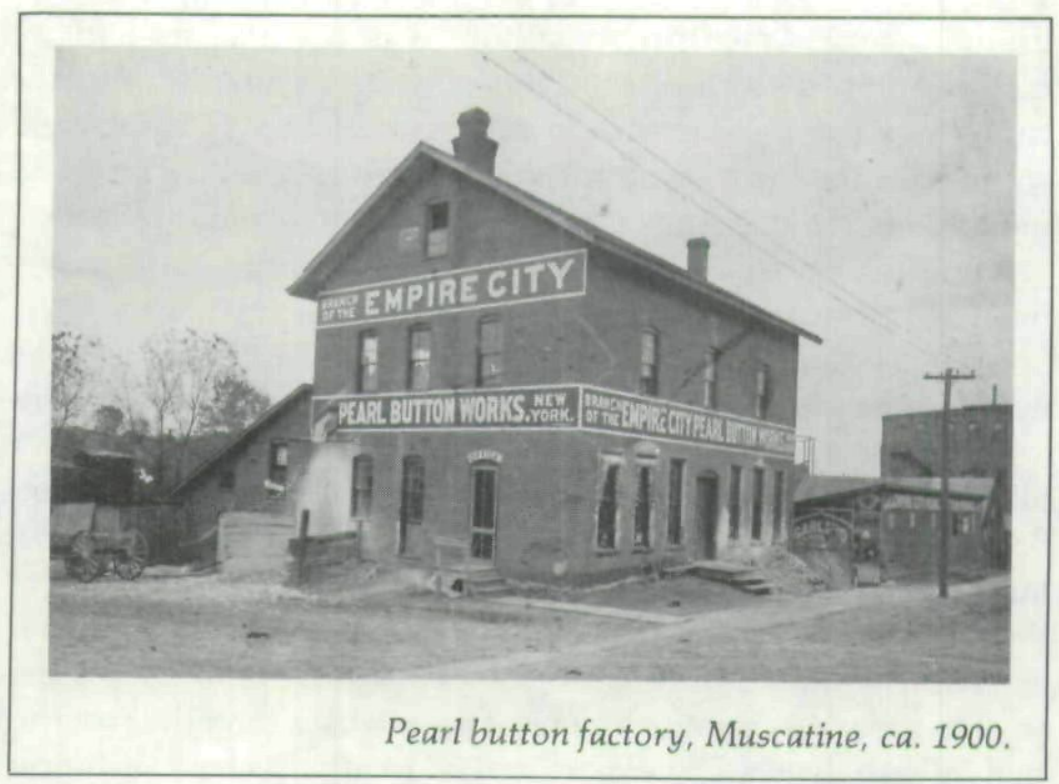

workers' health and safety. In 1900 the first Iowa Labor Commissioner to inspect factories found large numbers of fire traps, unguarded machinery, and unsanitary conditions. According to the Commissioner's report, working conditions for some twothirds to three-fourths of the workers were hazardous to their health and safety. In a 1912 study of work accidents in Iowa, E. H. Downey judged that the yearly number of accidents was two to three times greater than the 3,351 incidents reported by the State Bureau of Labor in $1910 .^{5}$

In 1911, no wage or hour protective legislation existed for women workers in Iowa who averaged 15 percent of the state's wage-earning population. Despite the Factory Act of 1902 which prohibited children fourteen years and younger from working, a 1904 special report found over 2,500 children fifteen years and younger working in industrial establishments. It was clear to most investigators, then and afterwards, that manufacturers were succeeding in circumventing the child labor legislation, that local authorities were often "criminally neg-

5. Keach Johnson, "Iowa's Industrial Roots: Some Social and Political Problems," Annals of Iowa 44 (Winter and Spring 1978): 249-252, 262, 266267; Iowa Bureau of Labor Statistics, Ninth Biennial Report, 1899-1900 (Des Moines, 1901), 6-22. 
ligent," and that state labor legislation in Iowa was far behind the nation in protecting workers. ${ }^{6}$

The distance between industrial centers hindered the organization of large inter-city workers' protective unions. The small size of most Iowa factories further discouraged trade union formation. Over half of Iowa's factories employed less than fifty workers each, compared to New England and North Atlantic states where the majority of factories employed over one hundred workers. While local labor unions in Iowa were numerous in the early 1900s, the large building trade unions were the only unions of significant power until the 1930s. ${ }^{7}$

Muscatine in 1911 was in many ways reflective of a typical Iowa industrial city. It was one of the seventeen cities in 1910 with a population of over ten thousand. The major industries were established fairly early: by 1900 the city had 105 industrial establishments; it added only eight by 1910 . Characteristic of Iowa's poor labor conditions, in 1910 Muscatine County was among the top ten Iowa counties most in need of factory improvements recommended by the State Labor Commission. ${ }^{8}$

Muscatine was distinguished by the fresh-water pearl button industry that dominated the city's manufacturing. Muscatine led the production of fresh-water pearl buttons in the state, second only to New York State in 1905. In 1910 almost two-thirds of Iowa's fresh-water pearl button employees worked in the forty-three plants in Muscatine. Of the city's 3,500 wage earners, over half were button workers. ${ }^{9}$

The first fresh-water pearl button industry in the world was started in 1891 in Muscatine by John F. Boepple, a German immigrant. Boepple traveled to the Midwest in the $1880 \mathrm{~s}$

6. Iowa Bureau of Labor Statistics, Fifteenth Biennial Report, 1910-1911 (Des Moines, 1912); Johnson, "Iowa's Industrial Roots," 263-271; Gallaher, Status of Women, 148.

7. Albert M. Jarvis, "Unionism in Iowa Before 1914" (M.A. thesis, University of Iowa, 1928), ii, vi, xiii; Thirteenth Census, 469.

8. In 1910 Muscatine's population was 16,178. Thirteenth Census, 690, 703.

9. Thirteenth Census, $684,690$. 
searching for an abundant source of river shells from which he could cut buttons. He found such a source in the shallows and banks of the Mississippi around Muscatine and began to cut buttons with a simple hand-run machine. The industry quickly boomed and drew entire families into the business of digging clams and manufacturing crude buttons in woodshed "factories." Machines were inefficient, worksmanship was poor, and living conditions were chaotic in the shack towns on the river banks. By 1900 an automatic button cutting machine had been invented, sky-rocketing the industry so that by 1905 over half of all button factories were making fresh-water pearl buttons. (Buttons were also made from metal, salt-water pearl shells, vegetable ivory, cloth, and bone.) In 1897 there were three button factories in Muscatine; within four years the number jumped to twenty-seven; and by 1911, forty-three factories in Muscatine were involved in button manufacturing. ${ }^{10}$

These factories varied in size and type of production. There were ten large "finishing" plants that included all stages of machine work, and six which merely cut the shells into the round button shapes, called blanks. Factories involved in one stage of production sold to other Muscatine factories as did many of the twenty-seven button factories outside Muscatine.

All work in the button factories was sex segregated. The button industry ranked fourth among the state's industries in the number of women employed. Conditions for female workers were notoriously bad, causing one journalist in 1911 to declare that women's work in the Muscatine button factories was worse than that in the large garment industry at that time. The machine and manual work for both sexes was unpleasant, however. The work demanded few skills for the tedious assembly line of specialized tasks. Button making in 1911 was hardly the artisan craft that it once was for John Boepple. ${ }^{11}$

The process for making buttons from fresh-water clam

10. Mike O'Hara, "Mr. Boepple and His Buttons," The Iowan 30 (Fall 1981):47; Frances S. Hurd, "The Pearl Button Industry of Muscatine, Iowa," Annals of Iowa 38 (Fall 1966):401; U.S. Bureau of the Census, Special Report of the Census Office: Manufactures, Part III, Selected Industries: Buttons (Washington, D.C., 1905), 207.

11. Thirteenth Census, 704; Pauline Newman, "The Strike of the Button 
shells began outside the factory where diggers dragged the river or lake with long rakes collecting clams. The clams were then fired to open the shells. The meat was scraped out and fed to hogs and the shells sold to button manufacturers. The factory work for manufacturing buttons involved both machine and manual work with unskilled and semi-skilled workers performing specialized tasks on the assembly line. At all stages of production, the buttons were handled individually since the shells varied in size and thickness.

The button cutters, who were all male, pulled the shells from the soaking vats where the remaining clam meat had been decaying from the shells. After days of soaking, the water in the vats was putrid and poisonous enough to cause blood poisoning and infections on the workers' hands and arms. The cutters used automatic tubular saw machines to cut blanks from the shells. The cutters' work rooms were damp and smelly and the air was thick with shell dust from the unventilated machines. Workers complained that the majority of both male and female workers had some form of throat disease or tuberculosis caused by the heavy dust.

Women worked automatic machines that drilled the button holes, pressed patterns, and polished the buttons. One investigator found the polishers to be mostly girls of fourteen and fifteen who arranged the buttons on a moving belt to be smoothed by the machinery. The polishing machines had no exhaust tubes and the workers breathed thick unfiltered shell dust. The drilling and pressing machines did have exhaust pipes, but the unprotected mechanisms frequently gashed or cut off workers' fingers. Despite a state law prohibiting women from cleaning machines in motion, women in the button factories were required to do so and often a fine was deducted from wages if the machine was not properly cleaned. Most women button workers were employed as sorters and button carders. Sorting rooms had large windows for lighting and large tables at which the women sat side by side separating and counting the finished buttons. Carders worked at home sewing buttons onto

Workers in Muscatine," The Progressive Woman, February 1912, 6; "Buttons -Pearl Buttons," Life and Labor, May 1911, 143. 
cardboard pieces to be sold at retail. Carders received one and a half cents for sewing a gross of buttons onto cards.

Most women, regardless of their job, were apparently paid by the finished piece. Piecework wages were the customary system of payment for women workers in industries around the country at this time. The piecework system encouraged women to work faster and longer and often to bring work home after hours. Typically the employers set wage scales by the working rate of the fastest workers and then lowered them when more women learned to work equally fast, thereby always encouraging more production for the same wage. Working hours varied from factory to factory. The 1910 lowa state manufacturing census reported that in the state, button factories employed the highest number of workers for fifty-four to sixty hours a week and the third highest number of workers for over seventy-two hours a week. ${ }^{12}$

The system of weighing and counting the finished buttons was always a major point of contention between the factory workers and their employers. The manufacturers paid workers on a gross of 168 buttons but sold the product on a normal gross of 144. The manufacturers' claim was that of every 168 buttons made, 24 would be imperfect. Workers argued that they were not getting paid for the time and labor of making the extra 24 buttons. Workers further suspected fraud in the weighing of the buttons and it was not until 1933 that workers were allowed to see their buttons weighed. Some factories held noon religious services for the workers at which time the management weighed the buttons and falsified the results. ${ }^{13}$

Prior to the formation of the button workers' protective union in 1910, there were two attempts at organizing the Muscatine button workers. These locals, founded in 1897 and 1903,

12. Of the few sources available on job descriptions and conditions of the Muscatine button workers, most are from factory investigations by women journalists for feminist or women's labor union periodicals. These sources support Pauline Newman's claim that working conditions for female workers were notoriously bad and also offer an insight into the large amount of women laborers' activism in the strike. Newman, "Strike of the Button Workers," 6; Annie MacLean, Wage-Earning Women (New York: Macmillan Co., 1910), 88; Thirteenth Census, 689.

13. Des Moines News, 15 April 1911; "Buttons-Pearl Buttons," 144. 
survived for a few years but eventually disintegrated with no labor victories. The monopoly that the button factories had over the labor and business of the city discouraged union activity. The large numbers of button workers offered great potential for unionization, however. Whole families worked in the factories, sons and daughters of local farmers lodged in the city to work, and many wealthy townswomen did piece work at home. Frequently, townspeople worked at a single button factory for most of a working career. Because of the wide spectrum and large numbers of workers, no class distinction existed between button workers and other laborers and city residents. Any intra-city conflict was between the consistently underpaid employees and the manufacturers. ${ }^{14}$

In early 1911, conditions were ripe for labor activity in Muscatine. Newspapers of previous months were riddled with reports of strikes all over the nation. The flood of garment strikes in 1910 and 1911 might well have been the cause for the manufacturers' claimed overproduction of buttons: fewer garments required buttons. Button workers complained of a cut in wages due to the production slow down. Furthermore, alongside the fearful growth of the button workers' union and other labor unions in the city, the recently established local Socialist party was strengthening.

IN EARLY NOVEmber 1910, a local Iowa union organizer founded the Muscatine Button Workers Protective Union, initially with a membership of nine men and twenty-nine women. By late January 1911 there were over one thousand members. The union, sensing the manufacturers' resistance, issued a sardonic statement refuting the rumor that the union was agitating: ". . . We were never on better terms with the employers than we are at the present time," the union statement read," . . . It was mentioned that the button cutters resented the cut in wages which certain factories made, but that state-

14. Iowa State Federation of Labor, Official Labor Directory, 1897-1911; Interview with Mabel Bartenhagen, 12 June 1974, Tape OHT-30, Musser Public Library, Muscatine, Iowa; Interview with Walter Conway, 23 March 1977, Tape OHT-75, Musser Public Library; Newman, "Strike of the Button Workers." 
ment . . . was given without our consent. We are all happy and content and have no cause of resentment." ${ }^{15}$ Despite such publicly claimed contentment, the union grew to 2,500 members and all but a few hundred button workers were in the union. The Muscatine News-Tribune claimed this to be the largest union in any city in Iowa. ${ }^{16}$

On February 25 all of the large button factories and all but one of the small ones announced a shutdown for an indefinite period. About 2,500 men and women workers were laid off. There is no report of the number of plants that originally shut down or the number of workers affected. Reports vary from "practically every factory" to only the large plants, and from 1,000 to 2,500 workers affected. Most newspapers report an "almost complete" shutdown. Eventually, all of the forty-three button factories in Muscatine shut down production.

Manufacturers later claimed that despite rumors that the new union would demand wage increases of up to 100 percent and that union officers had been appointed in each department of every factory, "the shutdown would not have been made on account of the union alone." A shutdown for December had already been planned due to overproduction and the recent financial depression in the East. ${ }^{17}$

The union immediately asserted that the shutdown was in fact a lockout intending to threaten workers out of the union. The lockout was "premeditated and without cause" because the union claimed it had never made demands on the employers nor did it contemplate such action. The union "fully realized that any action [on its part] would have furnished an excuse for the very move that the employers have made without any excuse." Furthermore, the continued operation of the button factories outside of Muscatine proved the financial argument false. If overproduction was really the cause of the shutdown, the manufacturers would not have offered re-employment to those workers who destroyed their union cards, or commenced pro-

15. "Buttons-Pearl Buttons," 143; Union statement quoted in Muscatine News-Tribune, 20 January 1911.

16. Muscatine News-Tribune, 20 January 1911.

17. Ibid., 16 March 1911. 
duction less than one month after the shutdown with non-union workers. ${ }^{18}$

Throughout March the button workers organized rapidly and peacefully. Despite a public belief that the shutdown would last only several weeks, the union organized with the intent of a longer siege. Political support and financial relief was requested immediately of local and national labor organizations. The response was encouraging. Samuel Gompers, president of the American Federation of Labor expressed his support and sent the AFL national treasurer to Muscatine. Emmett Flood, national organizer for the AFL, became a long-term coordinator for the union and the Women's Trade Union League sent four women to Muscatine to organize the women unionists and help in the relief committees. In the first six months of the shutdown the union hosted the president of the WTUL and the president of the Iowa State Federation of Labor. The state labor commissioner and the governor of Iowa also visited to investigate the situation. ${ }^{19}$

A large part of the city supported the unionists. The employment monopoly of the button industry was so complete that a majority of the townspeople had at one time or another worked in a button factory. The entire city felt threatened by the control that the industry had on employment and business. In the early weeks of the shutdown, unionists were publicly offered free meeting space, publicity, entertainment, housing, and food. ${ }^{20}$

The union maintained a tight organization from the beginning. A mass meeting of all unionists was held once every two weeks. Individual factory unions met daily, as did the executive board. The union opened a kitchen for single men and women unionists and issued scrip tickets with which union families bought food from supporting groceries. The union produced a newspaper and bulletins covering developments and representa-

18. Ibid.

19. Ibid., 5 March, 29 March, 7 April, 27 April 1911; Life and Labor, December 1911, 378.

20. Muscatine News-Tribune, 31 March 1911; Newman, "Strike of the Button Workers," 6. 
tives were continually sent to local unions and button factories. Pickets were held at the factories for many weeks. ${ }^{21}$

In light of the predominantly foreign born and ethnic membership of unions in other cities, labor reporters noted with surprise the great majority of native-born Anglo-Saxon members of the button workers' union. One Socialist reporter was greatly encouraged by the fact that western Americans were capable of organizing themselves. Of the approximately 2,500 union members, there were sixty Russians, fifteen black men, and a handful of Poles, Greeks, and Italians. Almost all of the women were native-born white Americans. For example, Pearl McGill, the secretary of the union, was a farmer's daughter who went into the button factories for temporary employment in order to pay her way through teacher's training. ${ }^{22}$

Women formed a necessary cooperative component of the union during the long shutdown. Organized into various committees, women arranged the housing, clothing, and feeding of the unemployed. Two women acted as representatives to the Chicago AFL. A committee of twelve women protested to the county attorney that an arrested woman unionist had been mistreated and subjected to foul language. Women were in the forefront of pickets and marches; four of the twelve members of the union executive committee were women. Women unionists were instrumental in the founding of the Juvenile Button Sewers' and Carriers' Union-the organization of about seven hundred children who had been carriers and button carders before the shutdown. ${ }^{23}$

During the shutdown women unionists leveled charges of sexual harassment at factory employers and managers. One source recalled a manager who was a notorious "womanizer." The union claimed that one manufacturer attempted to seduce a woman unionist and offered her money if she would spy on the union for him. One woman claimed that in the factory where she worked "the manager had a 'resting room' where some of

21. Muscatine News-Tribune, 4 March, 14 April 1911; "Buttons-Pearl Buttons," 144.

22. Newman, "Strike of the Button Workers," 6.

23. Life and Labor, December 1911, 278; Newman, "Strike of the Button Workers," 6. 


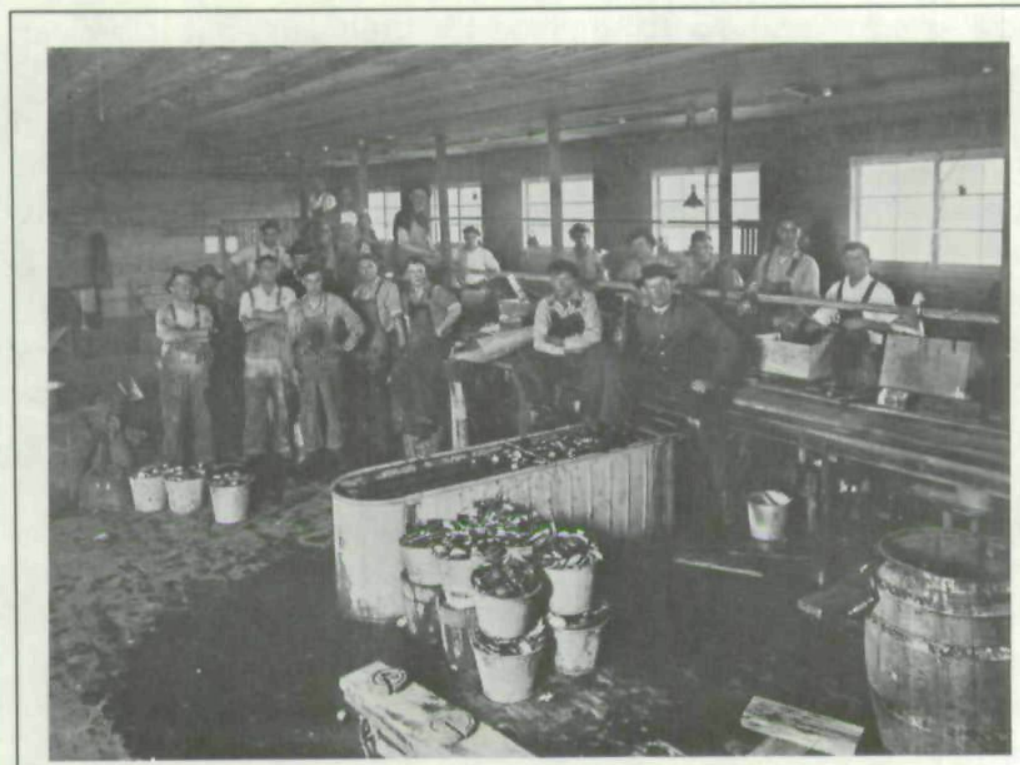

Button factory assembly line,

Muscatine, ca. 1912.

the girls had, at one time or another, to give in to his devilish demands, and for which they were reciprocated with a steady job. Those who did not comply with his wishes were discharged." Women workers from other factories made similar claims; once on strike, they were willing to admit incidents of sexual harassment from the management. ${ }^{24}$

The strike encouraged the growth of the local Socialist party, which culminated in the March 6 city election of two Socialist aldermen. The Muscatine News-Tribune charged that the two-week-old button industry shutdown was directly responsible for the Socialist gains and that at least 65 percent of the button workers voted the Socialist ticket. O. C. Wilson, who was one of the victors, served much of his term as business agent for the button workers' union. Although this was the first Socialist victory in a city election in Iowa, the Socialist influence should not be over-emphasized. The local and national

24. "Girls Beware," Button Workers Union Bulletin, Musser Public Library; Newman, "Strike of the Button Workers," 6; Philip S. Foner, Women and the American Labor Movement, 2 vols. (New York: Free Press, 1979), 1:357. 
Socialist party endorsed and aided the unionists, but it is clear that the union did not align itself with the party. ${ }^{25}$

The organizing activities of the button workers' union during the shutdown reflected a community atmosphere of mutual support and worker identification. The small and fairly isolated rural character of Muscatine might have encouraged, if not demanded, such cooperation and involvement from all sectors of the button workers' community. Traditional sex roles were partly broken when large numbers of women unionists took a hand in organizing relief activities and initiating protests, while many of the unemployed men worked in the union kitchen. Men and women who had previously worked in sexsegregated jobs collaborated to improve the working conditions of both. The aid of local townspeople and farmers was instrumental in forming a community of cooperative work. This strong community identity fostered a structure that carried the unionists through fifteen months of unemployment.

One lengthy negotiation attempt took place in the first weeks following the shutdown. John B. Lennon, national treasurer of the AFL, acted as arbitrator but the negotiations were abruptly broken off when the manufacturers refused to make any agreement that involved recognizing the union. Subsequently, the union issued its demands that: 1) manufacturers not discriminate in employment or pay on account of union membership, 2) a joint committee of manufacturers and workers be established to negotiate disputes, 3) all women workers see their buttons weighed, 4) all button workers be reinstated. "The fight now hinges on the recognition of the union," said one member of the union executive board in midMarch. In an atmosphere of growing tension, the union voted to continue the boycott despite the opening of the factories under reduced production. ${ }^{26}$

\section{$\mathrm{B}_{\mathrm{x}}$}

LATE MARCH, local and national conditions were running strongly against the odds of a peaceful settlement. On March 26, newspapers reverberated with reports of the disastrous

25. Muscatine News-Tribune, 7 March 1911.

26. Ibid., 17 March, 19 March 1911. 
Triangle Fire in New York City where 146 women died in their factories. Like many Iowa factories, the Triangle Shirtwaist Company building was over-crowded, ill-equipped with fire escapes, and notorious for dangerous working conditions.

In Muscatine various union disturbances caused the city mayor to issue a proclamation warning the unionists of state interference if there was more violence. The union warned its members to stay away from the factories where the disturbances had occurred when non-union scabs entered and left the factories. From the end of March through mid-April there was minor rioting daily at the factories and at the homes of scab workers. The mayor and non-union men and women were pelted with eggs, an acid bomb was thrown in the window of a scab worker's home, and eleven unionists were arrested. ${ }^{27}$

On April 13, at the request of the local sheriff, twenty-five strike breakers were brought into Muscatine from Chicago and St. Louis to act as authorized deputies of peace. A new unlawful assembly law prohibited the public congregation of more than three people. Local sources reported that the importation of the strike breakers caused more disruption to the community than the earlier union pickets and rallies. Called "sluggers" and "plug-uglies" by local residents, the strike breakers patrolled the streets with bats, enforcing the unlawful assembly law by "slugging anybody they thought was a button cutter." 28

On the night after the strike breakers' arrival, the unionists and about five thousand townspeople broke into a city-wide riot, precipitated by a strike breaker kicking a small girl earlier that day. The city police came to the aid of the strike breakers, but the crowd succeeded in driving them into their hotel. One source recalled that the crowd planned to burn the strike breakers alive in the hotel, until, ". . . The sheriff got up and said . . . 'if you don't do this, we will get these people out of town tomorrow.' And he did. But he brought in the state militia. . . ."29 Three companies of the state militia entered

27. Ibid., 18 March, 1 April, 2 April, 12 April 1911; Des Moines News, 12 April 1911.

28. Muscatine News-Tribune, 14 April 1911; Des Moines News, 12 April 1911; Interview with Mabel Bartenhagen.

29. Interview with Walter Conway. 
the city April 14 and stayed for four days under martial law.

On April 15 the Des Moines News reported that the strike breakers had been hired by the button manufacturers to agitate trouble in order to bring the state militia into the city. The logic was that troops would intimidate the unionists so that they would go back to work, and that troops could only enter the city under orders of a governor convinced that troops were necessary. "The locked-out union did not cause the trouble. They were as orderly as usual. But promiscuously knocking down old men, women, and children ... the imported Chicago toughs speedily dragged Muscatine into a state of anarchy and the Governor succumbed to the demands for troops."

In fact, the unionists had not been exceedingly orderly, as preceding weeks had shown. But the manufacturers could have had a hand in the agitation. At least five manufacturers wrote Governor Carroll on March 17 asking for militia protection from the "riotous mob." All of the letters claimed violence and rioting, but the governor refused to send the militia at that time. Ironically, the same day that the manufacturers wrote in concert to Governor Carroll asking for the militia, the Muscatine News-Tribune reported that "the union fears that something will be precipitated by hot-headed ones and the union will get the blame." ${ }^{31}$

Two settlements were arranged within the next month. The latter, in early May, was reached through the intervention of Governor Carroll. Both times the union broke the settlement. By mid-May the situation had reached a plateau of mistrust and antagonism that would keep the union boycotting for twelve more months.

Unionists claimed that the settlements were too vague,

30. Des Moines News, 15 April 1911.

31. Muscatine News-Tribune, 17 March 1911; Amsterdam Button Co. to Carroll, U.S. Button Co. to Carroll, Leo H. Hirsch and Co. to Carroll, Hawkeye Pearl Button Co. to Carroll, McKee-Bliven Button Co. to Carroll, 17 March 1911, Military Correspondence, Governor Beryl F. Carroll Papers, State Archives, Division of Historical Museum and Archives, Iowa State Historical Department, Des Moines, Iowa. 
leaving workers' disputes up to individual factory negotiations. The union claimed that the manufacturers had broken the settlements first by firing at least fifteen union workers and cutting wages. Attacks on manufacturers became increasingly personal, directed at specific "union haters" and "character assassins" who were black-listing fired unionists, attempting to bribe workers out of the union, and controlling the press and public investigations of the factories. "Is a man who boasts that he will starve those who have worked for him for years ... entitled to any consideration at the hands of anyone who has any sense of humanity? ... Would the town be worse off if he moved away?" the union demanded in a special bulletin. ${ }^{32}$

At least one manufacturer was sincerely trying to reconcile with the union and stabilize the situation. He complained to the governor that in spite of his efforts to encourage his colleagues to negotiate, ". . . . at the workers' meeting last night they stated that my work during the past week has simply been a bluff and that I was a bluffer from start to finish." Other factory owners were less amenable to reconciliation. John B. Lennon of the AFL admitted to Governor Carroll that on both sides the situation was nearly hopeless. "I cannot get [Mr. Umlandt of the Automatic Button Company] to say anything definite. He will talk about matters that are past but as to the future of putting his people back to work, he simply says that he is not ready to say what he will do." ${ }^{33}$

The alienation was certainly intensified by the union's practice of name-calling and the manufacturers' public demonstrations of power politics. Because of the nature of the community, unionists and other wage earners were often acquainted with the families of the manufacturers. Pin-pointing individuals as the cause of the trouble was highly instrumental in perpetuating the problem. Manufacturers maintained an aloofness from the conflict with public displays that their factories were functioning without union workers and that they

32. Button Workers Bulletin (Special Edition), Musser Public Library.

33. H. W. Huttig (Huttig Manufacturing Co.) to Carroll, 9 May 1911; John B. Lennon to Carroll, 22 May 1911, Military Correspondence, Governor Beryl F. Carroll Papers. 
would under no circumstances arbitrate with, or even discuss, the union. Their efforts to minimize the problem were apparently aided by the local newspapers.

While the manufacturers' near monopoly gave them a strong political advantage in both local and state government, the button workers' union supplemented their local community support with nation-wide union news coverage and financial support. By the end of the controversy in the spring of 1912, the union had received over $\$ 57,000$ from trade unions as far away as Fresno, California and as large as the Western Federation of Miners. The AFL contributed $\$ 21,500$ as strike benefits. The union used nearly all of these funds for local support and union

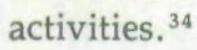

News coverage and union reports lessened following the first few months of the strike. The Democratic Muscatine NewsTribune which was sympathetic to the union in the first three months of the strike, abruptly stopped coverage of the labor situation in mid-May. Other local and state newspapers covered the Muscatine labor story only infrequently after the initial three months. This limited documentation allows only conjectures about the reasons for the final abandonment of the boycott in the late spring of 1912 .

The button manufacturers' political and financial pressure on the newspapers might have caused the cutback of local news coverage. Diminishing publicity also might have been a symptom of the extended conflict. Local community support apparently lessened during the fifteen-month boycott. The financial backing of the unionists by sympathetic members of the community in the first few weeks of the shutdown could hardly have been sustained for long. Likewise, despite national union support, the 2,500 button workers first laid off by the shutdown could not have tolerated more than fifteen months of continued unemployment. Since button factories offered the majority of employment in Muscatine, unemployed unionists would have had difficulty finding other employment. This would be especially true if the black-listing practices of the button manufacturers claimed by the unionists were effective

34. Life and Labor, December 1911, 378. 
outside of the button factories. In such an employment vacuum, the entire community was affected financially. As well, continued riots and a second state militia occupation of the city in the autumn of 1911 offended and irritated residents on both sides of the issue. The continued boycott must have become an increasingly exhausting and hopeless burden to both the strikers and the community.

The dominant agrarian attitudes in Iowa ultimately affected the progress and outcome of the labor conflict. Lack of state labor laws allowed the labor conditions which initiated the strike. The lack of state manufacturing laws caused local manufacturers to bond together for support and allowed manufacturers' aggressive hold in strike situations, such as the shutdown, the importation of the strike breakers and the state militia, and possibly much control of the local newspapers. These conditions were set in an environment where urbanindustrial conflict was an anomaly to the ethnically homogeneous and close-knit community.

In the spring of 1912, the Federal Council Commission of the Churches of Christ investigated the situation in Muscatine. Finding that the original labor versus capital conflict had become obscured in the preceding year of the strike, the resulting report focused on the broader community situation from which the conflict initially arose. The report emphasized "... the common failure of a community to realize that a local industry largely determines the community welfare, and is, therefore, a matter of public concern. . . . Consequentially, the community must interest itself not simply in getting the strike settled, but in getting the button industry organized on a basis of justice and efficiency." ${ }^{35}$ The button workers' strike of 1911-12 was indeed a matter of public concern, but it soon became a community burden which neither the manufacturer nor the community was willing or ready to negotiate.

The Churches of Christ report recommended state investigations of the counting system in the button factories, shell poisoning and other occupational diseases, night homework and employment, and conduct of the strike breakers in April

35. Quoted in Life and Labor, July 1912, 220-221. 
1911. As constructive social legislation, the report recommended the formation of a state industrial commission, similar to those in existence in other agricultural states with growing industrial interests. Soon after this report, the button workers strike ended, with neither the union nor the manufacturers claiming victory. The union disintegrated in everything but name. The community seemingly was more than willing to forget the issue.

In 1933 a new button workers' union staged a massive strike, gained recognition, and improved working conditions for the button workers in Muscatine. Within a few years, however, the fresh-water pearl button industry was on the decline due to the rise of cheap plastic. Today in Muscatine there is no fresh-water pearl button manufacturing, although a few of the old factories have converted to plastic button manufacturing. The process of making plastic buttons remains much the same, although resin has replaced shells and machines have advanced to higher efficiency.

Muscatine never developed into a large industrial center, perhaps because of the rise of plastics and the unfilled vacuum following the decline of the button factories. For whatever reasons, the community had a hand in deciding its own character. As seen in the industrial conflict of 1911-12, the community remained decidedly rural, despite opposing urbanindustrial pressures. 
Copyright of Annals of Iowa is the property of State of Iowa, by \& through the State Historical Society of Iowa and its content may not be copied or emailed to multiple sites or posted to a listserv without the copyright holder's express written permission. However, users may print, download, or email articles for individual use. 